\title{
DYNAMICS OF ELECTRIC ENERGY POLICY \\ THE COAL SECTOR IN INDONESIA: ANOMALY OR EXCEPTION?
}

\author{
Andreas Tedy Mulyono \\ Faculty of Law, Pelita Harapan University \\ andreas.mulyono@lecturer.uph.edu
}

\begin{abstract}
The dynamics of coal primary energy policy in Indonesia are still relevant to observe. On the one hand, coal commodity is a counter discourse in the mainstreem of green energy. On the other hand, the issue of the national electricity-energy crisis occurs due to obstruction of the primary energy supply chain. These two things are the challenge to the paradigm of energy resources as a capital for national development. Therefore, the issue of policy change in this case always needs to be studied. Analysis using normative juridical methods; in general related to the national energy policy and specifically on regulating coal mining to meet PLN's needs. The conclusion is that the prevailing laws and regulations have mandated the policy of national energy security. However, local utilization of coal needs to be regulated in a harmonious, transparent, and independent manner. The transparency and independence of coal primary energy development policies can be seen as an anomaly of the universal-global green energy paradigm. At least this is a temporary exception for Indonesia. Ensuring meeting our local's energy needs should be a priority for the next few decades.
\end{abstract}

Keywords: Energy Policy, Coal Sector, Anomaly, Exception.

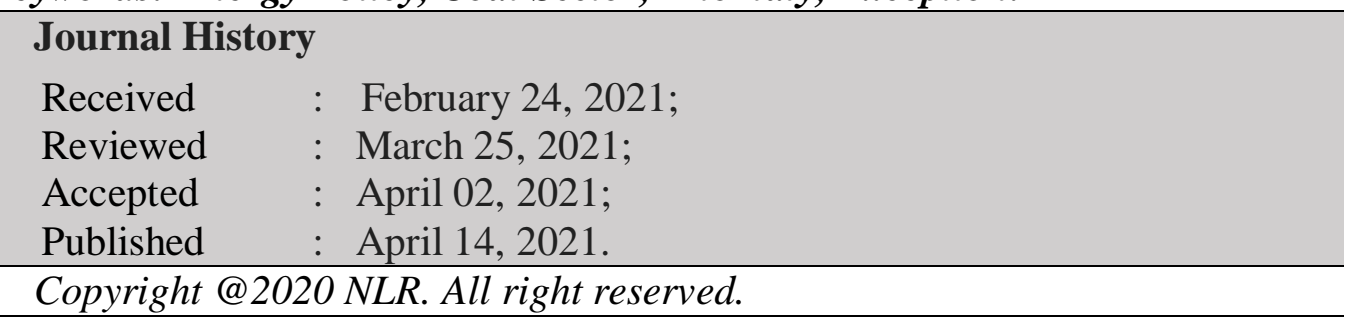

\section{INTRODUCTION}

The electricity crisis in early 2021 had emerged. Reportedly, parts of Indonesia will experience blackouts. There are rumors that PT PLN (Pesero) has difficulty in supplying coal so that the main power plant will be disrupted. Confirmation from the Government stated that there was a natural disaster ${ }^{1}$. The coal supply chain is an issue over the possibility of power outages in Jamali (Java, Madura and Bali). This is understandable because the contribution of coal as primary energy is still dominant. ${ }^{2}$

$1 \quad$ https://ekonomi.bisnis.com/read/20210121/44/1345876/sah-pasokan-batu-bara-kepembangkit-listrik-tersendat> diakses 18-2-2021.

${ }^{2}$ Rida Mulyana, Direktur Jenderal Ketenagalistrikan, Kementerian Minerba menyebutkan bahwa dari rata-rata beban puncak sistem listrik Jamali 25 Gigawatt, batu bara menyokong sekitar 16 Gigawatt atau sekitar 65\%. ( Konferensi Pers daring: "Rantai Pasok Energi Primer Pembangkit Listrik", 27 Januari 2021) 
The coal supply chain generally goes through four points. From upstream to downstream, namely transportation from: (i) exploration and exploitation locations to mine stockpiles; (ii) mine stockpile to the port of loading of origin; (iii) port of loading of origin to port of destination; (iv) port of destination to the location of the power plant. This supply chain problem will continue to emerge due to the dependence of PLTU PT PLN (Persero) on coal. Projections from year to year indicate this need. In fact, it tends to increase.

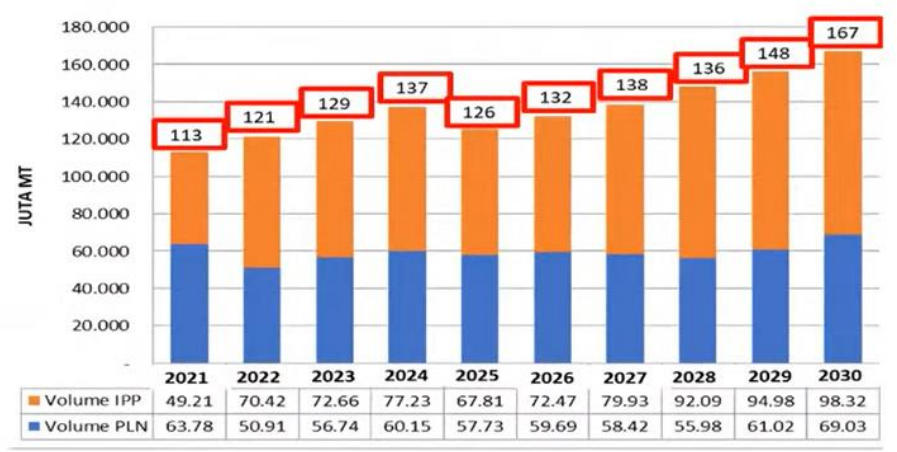

\section{PLN Coal Requirement Plan 2021 - 2030}

\section{Source: www.economist.com}

PLN predicts an increase in coal demand from 113 million metric tons in 2021 to 167 million metric tons in $2030 .^{3}$

Thus, it is not a shame and taboo to admit that we still need coal as a national primary energy resource. Although the propaganda from developed countries has resulted in reluctance to those who talk about business development in the coal sector. However, historically we can prove several signs that support the efforts of every sovereign state. For example, rich countries such as England and Norway. The two countries are aggressively promoting environmental issues in

\footnotetext{
${ }^{3}$ www.pln.co.id.> diakses 23-2-2021.
}

developing countries such as Indonesia. Even though in early 2021, Britain is still developing coal with large deposits in the country for the next 30 years of mining ${ }^{4}$. Also Norway, which in fact has long been "saving" the results of the petroleum sector.

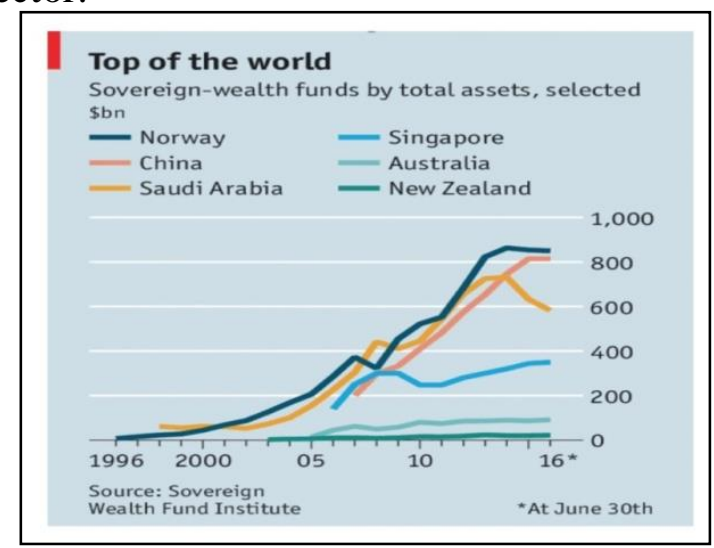

Source: www.pln.co.id

Note: subject to change according to approval.

Since 1969, Norway has mined a large amount of petroleum. Offshore oil mining in the country dramatically improves the national economy. Then in 1990, the Parliament supported it by issuing provisions on wealth funds. The results of this exploitation grew extraordinarily. Until now, the oil export proceeds have made Norway's sovereignwealth fund the largest in the world. Its official name is now Government Pension Fund Global. Such a large amount of funds, so that the management by the Norwegian central bank is under the supervision of the Ministry of Finance. ${ }^{5}$ It

${ }^{4}$ In early 2021, the UK Government plans to build a deep coal mine in cumbria, north-west England. Whereas the UK what is going on is Coal In 2025. View: https://edition.cnn.com/2021/02/17/world/clim ate-hypocrites-uk-canada-norwayintl/index.html> diakses 23-2-2021.

5 GPFG owns about $1.4 \%$ of total global holdings. Worth 1.1 trillion dollars (USD) and 8.6 trillion KRON invested in more 
should be noted that various parties criticized the policies of developed countries which tended to be hypocritical. ${ }^{6}$

Large countries such as the United States (US) also experience difficulties in developing energy policies. Nancy $K$. Kubasek and Garry S. Silverman acknowledge that energy policy is very complex. "... we must consider not only issues of resource depletion, but also the effects of alternate forms of energy on the environment." Every effort has been made to create an energy policy in the US, "... anything but consistent."7

Neutrally, it is stated that the challenges are the same, namely focusing on meeting national energy demand. The national energy policy is designed in such a way. But the result is a back and forth between "complacency" and an energy crisis (crisis). On the one hand, it is the belief that energy resources are not limited (un-limited) so that the Government tries to develop it to its full potential. On the other hand, the view is that energy is limited (limited) so that conservation policies are needed as well as a reduction in national energy consumption. ${ }^{8}$ It is difficult to develop consistent energy policies.

For coal, actually based on the description above, there are two reasons

than 9,000 companies in 72 countries. See:https://sevenpillarsinstitute.org/ethicalinvesting-norways-sovereign-wealth-fund/> diakses $23-2-2021$.

https://edition.cnn.com/2021/02/17/world/clim ate-hypocrites-uk-canada-norwayintl/index.html> diakses 23-2-2021.

7 Kubasek, Nancy K. and Garry S. Silverman. Environmental Law. 8th ed. 2014. Pearson Education, Inc., Prentice Hall, New Jersey 07458, pp. 310-313.

${ }^{8}$ Ibid. why this traditional fuel needs a regulatory solution. First, because the quantity is limited so that one day it will run out. Second, because it is considered to cause many environmental problems. For the first reason, the solution offered is to find other alternatives as a new energy source (substitution). So the regulation in this case does not stop the policy of developing coal exploration and exploitation. For the second reason, the solution offered is to find a coal mining method that does not harm the environment. The policy related to this is not by stopping the coal mining business. It's the mining industry setting. For example, with post-mining land restoration and surface mining procedures $^{9}$. At first glance, the dynamics of the US national energy regulatory system are similar to those of Indonesia. We also face the problem of domestic energy consumption which is so large, while the supply of primary energy is still minimal, so there is a potential for a crisis.

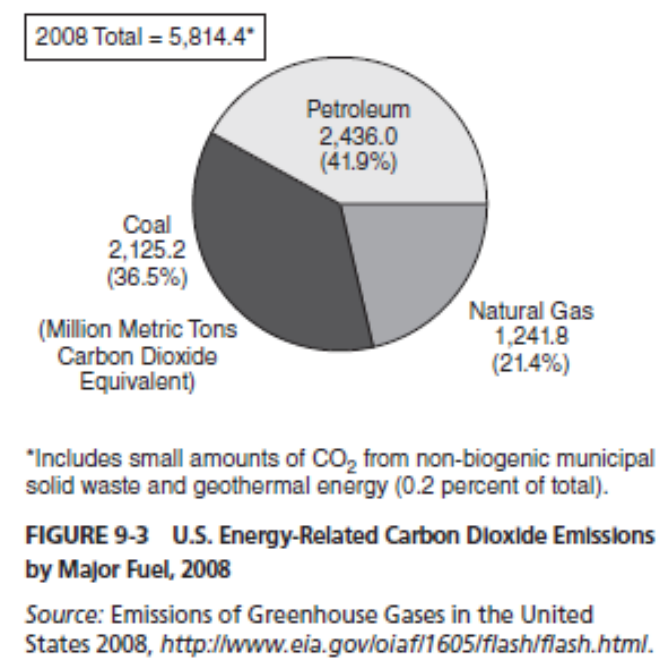

Source: Nancy K. Kubasek and Garry S. Silverman. Environment 8th ed. 2014. Pearson Education, Inc., Prentice Hall, New Jersey 0 pp. 321.

9 Differentiation of arrangements between contour mining, area mining, and open-pit mining. Ibid., pp. 320-325. 
The US also relies heavily on coal potential. Hydrocarbon reserves are able to meet $90 \%$ of national energy needs, where coal supplies 25\%. Coal is also very important because it is used by $50 \%$ of electricity generation. This also reduces US dependence on petroleum imports, which is burdensome for the state budget. Even the US is optimistic about its coal reserves of up to hundreds of years: "..., we have sufficient reserves to last approximately 250 years". ${ }^{10}$

\section{METHOD}

Legal research is a form of scientific activity, which is based on methods, systematics, and certain thoughts, which aim to study one or several phenomena of a particular law, by analyzing it. In studying the phenomenon of law, it requires an in-depth analysis of the problems at hand. The research method used is a normative legal research method and the approach used is a statutory approach (normative approach) and a conceptual approach.

Marzuki in Eka NAM Sihombing (2019) states that the normative juridical legal research method is a method that uses an approach that is based on the main legal material by examining theories, concepts of legal principles, norms, rules of legislation, court decision, agreement. The nature of the research used in this paper is prescriptive, adhering to the characteristics of legal science as an applied science, the prescriptions given in legal research activities must be able and possible to be applied. Therefore what is

${ }^{10}$ Kubasek, Nancy K. and Garry S. Silverman. Environmental Law. 2th ed. 1997. Pearson Education, Inc., Prentice Hall, New Jersey 07458, pp. 223. produced by legal research, even if it is not a new legal principle or a new theory, is at least a new argument. ${ }^{11}$

\section{DISCUSSION}

Changes in national policies related to primary energy in Indonesia require a different perspective. Unusual, nonmainstream perspective. Apart from being cross-sectoral in the country, national policies also need to be reviewed transnationally (tranfrontier). Therefore, this discussion will begin by examining various laws and regulations relating to: (i) national energy security; (ii) mineral and coal exploration and exploitation business activities; and (iii) meeting the need for coal-fired power plants. This research approach then points to a national policy priority related to primary energy in the coal sector.

\section{Hold or not National Energy}

Since 2007 our laws and regulations have explicitly promoted national energy security policies. Apart from focusing on the design and formulation of the national energy policy $(\mathrm{KEN})$ and the national energy general plan (RUEN); also stipulates measures to overcome domestic energy crises and emergencies. This important task is mandated by Law Number 30 of 2007 concerning Energy to the National Economic Council (DEN) ${ }^{12}$. DEN is also in charge of supervising the

11 Eka N.A.M Sihombing, Eksistensi Paralegal dalam Pemberian Bantuan Hukum bagi Masyarakat Miskin (The Existence of Paralegals in Providing Legal Aid to the Poor), Jurnal Ilmiah Penegakan Hukum, Vol. 6, No. 1, June(2019).

12 See: Article 12 paragraph (2) of Law No. 30 of 2007 on Energy. LN RI: $2007-$ 96; TLN: 4746. 
implementation of cross-sectoral energy policies. In general, this Law becomes the legal basis and long-term guidelines for regulating and managing the national energy sector. ${ }^{13}$

Law Number 30 of 2007 concerning Energy also explains that energy resources are strategic natural resources and are very important for the lives of the people at large. There are at least three reasons why energy resources must be controlled by the state and used maximally for the prosperity of the people. First, increasing economic activity. Second, increasing job opportunities. Third, national resilience.

Next on 17 October 2014, the issuance of Government Regulation (PP) Number 79 concerning National Energy Policy (KEN). KEN is the mandate of Article 11 paragraph (2) of Law Number 30 of 2007. This means that the PP appears seven years after being mandated after the approval of the DPR (DPR Decree Number 01 / DPR RI / III / 2013-2014).

Three years after KEN or about a decade after the mandate of the law, the issuance of Presidential Regulation Number 22 of 2017 concerning the General Plan for National Energy (RUEN). On March 2 2017, President Jokowi signed the Presidential Decree. After being agreed at the 3rd DEN Plenary Session on June 22, 2016.

Even so, for a long time, the direction of the national energy policy launched at that time was guided by a qualified paradigm. The paradigm is that energy resources are the capital of national development. It is no longer a mere export commodity. The elucidation in the RUEN attachment states seven objectives, namely: (i) realizing the independence of energy management; (ii) ensuring the availability of energy and meeting the needs of domestic energy sources; (iii) optimizing the management of energy resources in an integrated and sustainable manner; (iv) increase efficiency in energy utilization; (v) ensure fair and equitable access to energy; (vi) development of domestic technology, energy industry and energy services capabilities; (vii) creating jobs and controlling the impacts of climate change and maintaining environmental functions. $^{14}$

Originally there was a policy evaluation after it turned out that in 2021 there was still a threat of an electrical energy crisis. However, the stated goals may still be difficult. In addition, the Government is proclaiming the achievement of energy resources as national development capital in the period up to 2050. However, stakeholders must ensure that this national energy policy is still in the right corridor. For the sake of progressing national energy security.

If we correlate, beetween the regulation and the implementation, so we can analyze it from this principle. The 3 (three) principles referred to include the lex superior de rogat lex inferior principle, lex specialist derogate lex generalis, lex posterior de rogat lex priori. Jazim Hamidi further explained that based on the study of legal science 3 (three) principles as referred to are important pillars in understanding the construction of statutory law in Indonesia in detail, it can be explained that: a) The principle of lex superior de rogat lex inferior, higher

14 Presidential Regulation No. 22 of 2017 concerning The National Energy GeneralPlan. 
regulations will override lower regulation when regulating the same and conflicting substances. b) As a lex specialist derogat lex generalis principle, more specific rules will override general rules when regulating the same and contradictory substances. c) The principle of lex posterior de rogat lex priori, the new regulation will override the old regulation. ${ }^{15}$

The bright spot for supporting policies can be seen in February 2021. The government has issued PP No. 42 on the Ease of National Strategic Projects (PSN). One of the PSNs that has been facilitated is the Barru PLTU in South Sulawesi ${ }^{16}$. This PLTU with a capacity of 100 MW uses coal as fuel. This PLTU is a series of Government programs in order to accelerate the development of power plants spread across eight locations. These locations are Amurang, North Sulawesi with a capacity of $2 \times 25 \mathrm{MW}$, Konawe, Southeast Sulawesi with a capacity of $2 \times 15$ MW, Gorontalo with a capacity of 2x25 MW, Ternate, North Maluku with a capacity of $2 \times 7 \mathrm{MW}, 2 \times 10 \mathrm{MW}$ in Jayapura and Timika with a capacity of $2 \times 10$ and 2x7 MW respectively, and Ambon with a capacity $2 \times 10 \mathrm{MW}$. It is appropriate that the current Government puts forward the Electricity Infrastructure Development Program. The challenge is returning to the coal supply chain, starting

15 Eka N.A.M Sihombing, Cynthia Hadita, Analisis Wacana Hukuman Pancung Di Provinsi Aceh, Jurnal Legislasi Indonesia, Vol. 6, No. 4, December (2019).

16 See: Presidential Regulation No. 109 of 2020 concerning the Third Amendment to Presidential Regulation No. 3 of 2016 concerning the Acceleration of Implementation of National Strategic Projects; jo. Government Regulation No. 42 of 2021 on Ease of National Strategic Projects, LN RI: 52-2021, TLN: 6654. from the upstream coal mine to the PLN PLTU downstream.

\section{Distribution of Coal "Green Mine" Results}

Currently, the paradigm of energy resources as the capital for national development is still relevant. The main problem is the distribution of mining products and sustainable mine management. In general, Indonesia's natural resources are unevenly distributed in various regions of the Republic of Indonesia. Requires regulation in order to achieve a fair distribution. In addition, the challenges of environmentally friendly mining management also remain a concern. Universal - global environmental issues that face the people's mandate will be described separately in the following sections of this paper.

Law Number 4 of 2009 concerning Mineral and Coal Mining emphasizes the differences in the regulation of mineral and coal mining businesses that are separate from geothermal, oil and gas (oil and gas), and groundwater. ${ }^{17}$. This law is formulated to manage and exploit the potential of minerals and coal independently, reliably, transparently, competitively, efficiently, and with environmental insight, in order to guarantee sustainable national development. ${ }^{18}$ The General Elucidation Section also states that minerals and coal are un-renewable natural resources, "... their management needs to be carried out optimally, efficiently, transparently, sustainable and environmentally sound,

${ }^{17}$ Considerant of Law No. 4 of 2009 on Mineral and Coal Mining, LN RI: 4-2009; TLN: 4959. 
and equitable in order to obtain the greatest benefits for prosperity people"19.

After eleven years of effect, Law

Number 3 of 2020 concerning

Amendments to Law Number 4 of 2009 concerning Mineral and Coal Mining was issued. The consideration of these changes is so that they can become an effective, efficient and comprehensive legal basis in the operation of mineral and coal mining. ${ }^{20}$ It was explained that this improvement was to provide legal certainty in the management and exploitation of Mineral and Coal Mining activities in Indonesia. Thus, the use of minerals and coal in general has been mandated by these two laws.

In line with the profit-oriented coal business sector, the Government also needs to regulate the prioritization of the supply of coal needs for domestic interests. In this case, coal is one of the national energy sources, apart from exports. The provisions regarding this matter are explicitly stated in the section on the General Explanation of Government Regulation Number 23 of 2010 concerning the Implementation of Mining Business Activities. $^{21}$ (PP 23/2010). If there is price fluctuation, usually the local market and

${ }^{19}$ Hal ini sinergis dengan amanat Pasal 33 ayat (3) Undang-undang Dasar 1945 yang menyebutkan bahwa bumi, dan air, dan kekayaan alam yang terkandung di dalamnya dikuasai oleh negara dan dipergunakan untuk sebesar-besarnya kemakmuran rakyat.

${ }^{20}$ Considerant of Law No. 3 of 2020 on Amendments to Law No. 4 of 2009 concerning Mineral and Coal Mining, LN RI: 147-2020; TLN: 6525.

Considerant and General Explanation of Government Regulation No. 23 of 2010 concerning The Implementation of Minieral and Coal Mining Business Activities, LN RI: 29-2010; TLN: 5111. the export market generate different profit margins. Prices in export markets are often higher than in local markets.

To ensure domestic coal supply sources, the holders of Production Operation IUP and Production Operation IUPK must prioritize domestic interests which include the need for domestic processing and direct use industries. Exports can be implemented if domestic needs have been met. Article 84 PP 23/2010 regulates this.

More technically, the obligation to meet domestic needs (domestic market obligation, abbreviated as DMO) is determined based on Ministerial Regulations and Ministerial Decrees. Minister of Energy and Mineral Resources Regulation Number 25 of 2018 concerning Mineral and Coal Mining Business; Article 32 paragraph (2) reads: "The Minister determines the amount and type of coal needs to meet domestic needs." After that, the Minister of Energy and Mineral Resources issued Regulation Number 17 of 2020 concerning the Third Amendment to the Regulation of the Minister of Energy and Mineral Resources Number 25 of 2018 concerning Mineral and Coal Mining Business; where Article 62 stipulates that IUP and IUPK holders are required to prioritize the fulfillment of domestic mineral and coal needs and comply with production and sales controls.

Furthermore, the percentage and obligation for PLN to make long-term contracts to guarantee the DMO are regulated in the Minister of Energy and Mineral Resources Decree No. 255.K / 30 / MEM / 2020. The substances are: (a) determining the minimum percentage of DMO to the holders of Production Operation IUP, Production Operation 


\section{NOMO L LWEREWW}

IUPK, Production Operation PKP2B and IUPK as a continuation of contract / agreement operation of $25 \%$ of the planned total coal production in 2021 approved by the Government; and (b) business entities providing electricity for the public interest are required to make plans to meet coal demand for the following year by prioritizing the longterm contract mechanism.

The distribution aspect is also an important issue because coal mining locations are scattered in various regions. Based on the Letter of the Director of Energy of PT PLN (Persero) Number 2082 / EPI.01.01 / B01050000 / 2020 dated 11 September 2020, there are 54 coal supply companies to PLN. These coal mining sources are trusted to meet PLN's needs so far.

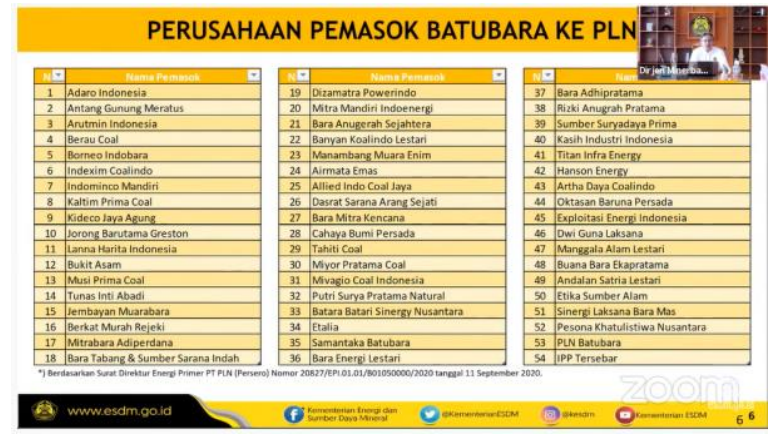

Source: Material of the ESDM Online Press Conference: "The Supply Chain of Primary Energy for Power Plants", 27 January 2021.

The supervisory function of these coal companies is regularly carried out by the Directorate General of Mineral and Coal in coordination with the Directorate General of Electricity and PT PLN (Persero). The goal is to immediately mitigate the risk of problems in the coal supply chain.

\section{Priority Mandate of the People: Do not be ashamed and not a taboo}

With regard to universal issues the global environment, it is necessary to agree that the people's mandate is a priority over everything. In particular, the President and the DPR RI, as representatives of the people, have mandated energy resources as the capital for national development (vide energy laws and regulations: Law 30/2007 on Energy; and Law 4/2009 in conjunction with Law 3/2020 on Minerba) ; as well as Law 30/2009 on Electricity. ${ }^{22}$ Although indeed awareness about this is not without challenges. The impact is that national policies that are not pro-people are more due to a "culture of shame" that is not yet in place.

Not only national political pressure which is full of interests, but also global political pressure (geopolitical tension). The variety of global challenges based on universal principles is very difficult to control. Massive propaganda tends to block the use of energy resources. Utilization of coal's primary energy is thought to destroy the ozone layer, the cause of global warming. Like petroleum, coal is a fossil energy that is always a world discourse connected with the pros and cons of climate change issues. Various Climate Change propaganda is found in many literatures ${ }^{23}$. Parallel with the various derivative concepts that have international environmental standards ${ }^{24}$,

22 Undang-undang Nomor 30 Tahun 2009 tentang Ketenagalistirkan, LN RI: 1332009; TLN: 5052.

23 Vanderheiden S. Climate Change. In: Chatterjee D.K. (eds) Encyclopedia of Global Justice. (Dordrecht, Springer (eBook), 2011).

24 Chatterjee D.K. International Environmental Standards. In: Chatterjee D.K. (eds). Encyclopedia of Global Justice. Deen K. Chatterjee. DOI: https://doi.org/10.1007/978-1-40209160-5_1047 
namely Biodiversity, Global Warming ${ }^{25}$ Green House Gas Effect ${ }^{26}$ Climate Justice $^{27}$, Climate Strike, Climate Adaptation dan seterusnya. The development of the coal sector is considered a misconception, against global trends, and avoiding national commitments (nationally determined contributions, NDC). ${ }^{28}$

Mirza Nasution in Hadita (2020) The authoritarian political configuration, is the composition of the political system that allows the state to play a very active role and takes almost all initiatives in making state policy. This configuration is marked by the drive of the power elite to impose unity, the elimination of open opposition, the dominance of the state leadership to determine state policy, and the dominance of political power by the eternal political elite, and there is a doctrine that justifies the concentration of power. ${ }^{29}$

https://link.springer.com/referenceworkentry/1 0.1007/978-1-4020-9160-5_1047> (Dordrecht: Springer (eBook), 2011)

${ }^{25}$ Rosenberg C. Global Warming. In: Chatterjee D.K. (eds) Encyclopedia of Global Justice. (Dordrecht: Springer (eBook), 2011).

26 Sven Teske (Ed.) Achieving the Paris Climate Agreement Goals: Global and Regional 100\% Renewable Energy Scenarios with Non-energy GHG Pathways for +1.50 and $+2 o C$. (Springer Open (eBook), 2019) http://extras.springer.com.

${ }^{27}$ Bernstein A.R. Climate Justice. In: Chatterjee D.K. (eds). Encyclopedia of Global Justice. (Dordrecht: Springer (eBook), 2011)

http://iesr.or.id/v2/publikasi_file/COMS-PUB0015_Coal-Dynamics-and-Energy-Transitionin-Indonesia-1.pdf> pp. 21-26.

${ }^{29}$ Cynthia Hadita, Regional Autonomy Political Politics Of Regional Liability Reports To Regional Representatives In The Implementation Of Local Government, Nomoi
Apart from that by sector, various challenges have emerged. The environmental and forestry sectors, for example, are often at odds with the industrial, mining and economic sectors. The harmony and synergy between these various sectors is still a scourge. This sectoral problem is allegedly also affected by political pressures. Legal breakthrough is needed to overcome it. When referring to the concept of Scientific Revolution, the emergence of anomaly is one sign of a paradigm shift. $^{30}$ Repeated legal breakthroughs become a necessity for innovative solutions. For example, a paradigm shift in "green energy" amidst the discourse of uncertainty and lack of legal benefits. Time will tell. A breakthrough or a new decision must be taken.

The government has always tried to find innovative solutions. The form is an effective legal corridor. The implementation of cross-sectoral, crossregional, and cross-stakeholder regulations needs to be integrated. The flagship is the Job Creation Law (Law 11/2020) ${ }^{31}$ with various implementing regulations. In early February 2021, the Government issued 45 government regulations (PP) and 4 presidential regulations (Perpres). Relevant examples include PP 21/2021 concerning Spatial Planning Implementation; PP 22/2021 concerning Organizing Environmental Protection and Management; PP 23/2021 concerning

Law Review, Volume 1, Issue 1, May 2020, p. 93.

30 Kuhn, Thomas S. The Structure of Scientific Revolutions. Third ed. The University of Chicago Press, Chicago and London. 1962, pp. 52-65.

31 Law No. 11 of 2020 on Copyright, TLN RI: 2020-245; TLN: 6573. 
Forestry Implementation ${ }^{32}$; PP 25/2021 concerning the Implementation of the Energy and Mineral Resources Sector ${ }^{33}$; PP 42/2021 concerning the Ease of National Strategic Projects ${ }^{34}$; and PP 43/2021 concerning Resolving inconsistencies in spatial planning, forest areas, permits and / or land rights. ${ }^{35}$ In fact, the various PP and Perpres are seen as one unit that is interrelated because it is an implementing regulation for Law 11/2020 (Cipta Kerja).

However, PP 25/2021 which regulates the Implementation of the EMR sector needs attention. Chapter II concerning Minerals and Coal, Article 3 provides incentives in the form of imposition of $0 \%$ (zero percent) royalty for holders of IUP, IUPK production operations and IUPK as a continuation of Contract / Agreement Operations for coal commodities that provide Coal Value Added activities in country (vide Article 3 paragraph (1)). The considerations are energy independence and fulfillment of industrial raw material needs (vide Article 3 paragraph (2)). PP 25/2021 also regulates Electricity (vide CHAPTER IV Articles 22 to 58). The government regulates many things, including providing funds for the development of electricity supply sourced from the APBN, APBD,

${ }^{32}$ Government Regulation Number 23 of 2021 concerning Forestry Implementation, LN RI: 33-2021, TLN: 6635.

${ }^{33}$ Government Regulation No. 25 of 2021 concerning Spatial Planning, LN RI: 352021, TLN: 6637.

${ }^{34}$ Government Regulation No. 42 of 2021 concerning Ease of National Strategic Projects, LN RI: 52-2021, TLN: 6654.

${ }^{35}$ Government Regulation No. 43 of 2021 concerning Settlement of Spatial Discrepancies, Forest Areas, Permits, and/or Land Rights, LN RI: 53-2021, TLN: 6655. and / or assistance from Electricity business entities.

The real results of this regulation through various PPs still need to be consistently enforced in its implementation in the field. However, this is sufficient to prove that the Government remains committed to developing primary energy in the coal sector for national energy security. It is not taboo if we want to show the existence and independence of the nation in meeting the electricity needs of its people.

\section{CONCLUSION}

Law Number 30 of 2007 concerning Energy and Law Number 4 of 2009 jo. Law Number 3 of 2009 concerning Minerals and Coal has mandated national energy security. Specifically, the primary energy supply chain in the coal sector from upstream is guaranteed by the provisions of the Domestic Market Obligation (DMO). However, the implementation of existing legal norms requires the awareness of stakeholders in order to regulate the local utilization of coal commodities that are harmonious, transparent, and independent. Transparency between sectors and the independence of coal primary energy development policies can be seen as anomalies of the global "green energy" paradigm. Because we need to relax the universal-global flow. Temporary exceptions for the sake of certainty in meeting people's energy needs for the next few decades.

\section{REFERENCES}

Bedjoui, Mehammad. Towards A New International Economic Order. (New York: Holmes and Meier Publishers Inc. (eBook), 1989). 


\section{NOMOI LWW REVEW}

Bradbrook, Adrian J., Rosemary Lyster, Richard L. Ottinger, Wang Xi (Eds.). The Law of Energy for Sustainable Development. IUCN Academy of Environmental Law Research Studies (v. 1). (Cambridge: Cambridge University Press (eBook), 2005). www.cambridge.org/97805218452 50.

Chatterjee, Deen K. International Environmental Standards. In: Chatterjee D.K. (eds) Encyclopedia of Global Justice. Deen K. Chatterjee. DOI: https://doi.org/10.1007/9781-4020-9160-5_1047 https://link.springer.com/reference workentry/10.1007/978-1-4020-

9160-5_1047>

(Dordrecth:

Springer (e-Book), 2011).

Craik, Neil. The International Law of Environmental Impact Assessment: Process, Substance and Integration. (Publisher: Cambridge University Press (eBook), 2008).

Hadita, Cynthia., Regional Autonomy Political Politics Of Regional Liability Reports To Regional Representatives In The Implementation Of Local Government, Nomoi Law Review, Volume 1, Issue 1, May (2020).

Hall, Matthew. Victims of Environmental Harm: Rights, Recognition and Redress Under National and International Law. (Publisher: Routledge (eBook), 2013).

Kubasek, Nancy K., and Gary S. Silverman. Environmental Law. $8^{\text {th }}$ Ed. (Publisher: Pearson Education, Prentice H. (eBook), 2014)
Environmental Law. 2th ed. 1997. (Pearson Education, Inc., Prentice Hall, New Jersey 07458. 1997.

Kuhn, Thomas S. The Structure of Scientific Revolutions. Third ed. (The University of Chicago Press, Chicago and London. 1962).

Louka, Elli. International Environmental Law - Fairness, Effectiveness, and World Order. (Publisher: Cambridge University Press (eBook), 2006).

Sihombing, Eka N.A.M., Eksistensi Paralegal dalam Pemberian Bantuan Hukum bagi Masyarakat Miskin (The Existence of Paralegals in Providing Legal Aid to the Poor), Jurnal Ilmiah Penegakan Hukum,Vol. 6, No. 1, June (2019).

Sihombing, Eka N.A.M., Cynthia Hadita, Analisis Wacana Hukuman Pancung Di Provinsi Aceh, Jurnal Legislasi Indonesia, Vol. 6, No. 4, December (2019).

Teske, Sven (Ed.) Achieving the Paris Climate Agreement Goals: Global and Regional 100\% Renewable Energy Scenarios with Non-energy GHG Pathways for $+1.5 o$ and $+2 o C$. (Springer Open (eBook), 2019) http://extras.springer.com.

Undang-Undang Dasar Negara Republik Indonesia Tahun 1945.

Undang-undang Nomor 11 tahun 2020 tentang Cipta Kerja, TLN RI: 2020-245; TLN: 6573.

Undang-undang Nomor 3 Tahun 2020 tentang Perubahan atas Undangundang Nomor 4 Tahun 2009 tentang Pertambangan Mineral dan Batubara, LN RI: 147-2020; TLN: 


\section{NOMOI LWW REVEW}

6525 .

Undang-Undang Nomor 32 Tahun 2009 tentang Perlindungan dan Pengelolaan Lingkungan Hidup, LN RI Nomor 140, Tahun 2009; TLN: 5059.

Undang-undang Nomor 30 Tahun 2009 tentang Ketenagalistirkan, LN RI: 133-2009; TLN: 5052.

Undang-undang Nomor 4 Tahun 2009 tentang Pertambangan Mineral dan Batubara, LN RI: 4-2009; TLN: 4959.

Undang-undang Nomor 30 Tahun 2007 tentang Energi. LN RI: 2007-96; TLN: 4746.

Peraturan Pemerintah Nomor 21 Tahun 2021 tentang Penyelenggaraan Penataan Ruang, LN RI: 31-2021, TLN: 6633.

Peraturan Pemerintah Nomor 22 Tahun 2021 tentang Penyelenggaraan Lingkungan Hidup, LN RI: 322021, TLN: 6634.

Peraturan Pemerintah Nomor 23 Tahun 2021 tentang Penyelenggaraan Kehutanan, LN RI: 33-2021, TLN: 6635.

Peraturan Pemerintah Nomor 25 Tahun 2021 tentang Penyelenggaraan Penataan Ruang, LN RI: 35-2021, TLN: 6637.

Peraturan Pemerintah Nomor 42 Tahun 2021 tentang Kemudahan Proyek Strategis Nasional, LN RI: 522021, TLN: 6654.

Peraturan Pemerintah Nomor 43 Tahun 2021 tentang Penyelesaian Ketidaksesuaian Tata Ruang, Kawasan Hutan, Izin, dan/atau Hak Atas Tanah, LN RI: 53-2021,
VOLUME 2, ISSUE 1

MAY 2021

TLN: 6655.

Peraturan Pemerintah Nomor 23 Tahun 2010 tentang Pelaksanaan Kegiatan Usaha Pertambangan Minieral dan Batu Bara, LN RI: 29-2010; TLN: 5111.

Peraturan Presiden Nomor 109 tahun 2020 tentang Perubahan Ketiga atas Peraturan Presiden Nomor 3 Tahun 2016 tentang Percepatan Pelaksanaan Proyek Strategis Nasional.

Peraturan Presiden Nomor 22 Tahun 2017 tentang Rencana Umum Energi Nasional.

https://ekonomi.bisnis.com/read/20210121 /44/1345876/sah-pasokan-batubara-ke-pembangkit-listriktersendat> diakses 18-2-2021.

www.pln.co.id.> diakses 23-2-2021. https://edition.cnn.com/2021/02/17/world/ climate-hypocrites-uk-canadanorway-intl/index.html> diakses 23-2-2021.

https://www.nbim.no/en/the-fund/aboutthe-fund/> diakses 23-2-2021.

https://sevenpillarsinstitute.org/ethicalinvesting-norways-sovereignwealth-fund/> diakses 23-2-2021.

https://edition.cnn.com/2021/02/17/world/ climate-hypocrites-uk-canadanorway-intl/index.html> diakses 23-2-2021. 